\section{RADIO AND ELECTRICAL ENGINEERS}

$\mathrm{T}$ HE application of electricity to signalling along wires in the latter half of the nineteenth century led to the foundation in 1871 of the Society of Telegraph Engineers. At a later date the title was changed to the Institution of Electrical Engineers and its scope expanded to enable it to cater for the interests of all those professionally engaged in electrical engineering in Great Britain. Moving with the growth and development of wireless telegraphy and telephony, the Institution inaugurated in 1919 a Wireless Section to deal with the subjects of highfrequency engineering and audio-frequency recording and reproduction. Shortly afterwards, the Institution was incorporated by Royal Charter, and the fully qualified members were granted the right to describe themselves as chartered electrical engineers. At the same time, it was recognized that, while maintaining the standard of the qualifications for membership, more opportunity should be afforded to the physicist engaged in radio work to become a member. It is particularly opportune to direct attention to this fact at the present time, when a large number of men engaged in scientific and technical radio work would probably describe themselves as radio physicists rather than as wireless or radio engineers. The Institution thus welcomes as potential members those who, although not having received the usual training of electrical engineers, nevertheless hold degrees or equivalent qualifications in physics and are fully expert in their own branch of radio technique. It is perhaps significant of the times to point out that for the past three years the president of the Institution of Electrical Engineers has been a member whose main professional interest has been in the field of telecommunications, the present holder of that office being Sir A. Stanley Angwin, engineer-in-chief of the Post Office.

On May 3 last, the Wireless Section of the Institution held a special meeting to commemorate the silver jubilee of its formation in 1919, and six past chairmen of the Section delivered short addresses which have now been published (J. Inst. Elect. Eng., 91, Part III, No. 15, September 1944). After an introductory address by the president, Dr. W. H. Eiccles gave a short account of the technical events in the early progress of wireless communication which led to the formation of the Wireless Section. Prof. G. W. O. Howe followed with a survey of the development of the principles and theory of the subject, with special reference to the properties of the ionosphere. The early development of wireless telegraphy in the Navy from 1899 onwards was dealt with by Admiral Sir Charles E. Kennedy-Purvis, who referred to the fact that the close co-operation between the Navy and the General Post Oifice has from the beginning been a characteristic feature in wireless progress in Britain. The life of the Wireless Section of the Institution 'of Electrical Engineers has coincided with the growth of practical wireless telephony, for it was in 1919 that the early experiments in the transmission of speech and music took place in Great Britain and paved the way for the development of broadcasting. Starting from this point, Mr. H. Bishop traced the history of the British Broadcasting Corporation and its activities in providing a British and Empire broadcasting service. He also referred to the growth of television, in which field, prior to the present War, Great Britain held a decisive lead over all others, including the United States of America. Finally, Dr. R. L. Smith-Rose attempted to portray what the future might have in store when the greatly increased knowledge and experience gained during the War becomes available for application to peace-time requirements. The whole field of radio communication and navigation, and of aural and visual broadcasting would make rapid and important advances; and Dr. Smith-Rose looked forward to the day when radio-controlled pilotless freight-carrying aircraft would fly distances comparable with that of the North Atlantic route between Great Britain and North America. Reference was also made to the heavy debt which all the applications and advances that were mentioned by the various speakers at the meeting owe to those patient investigators and research workers, who in recent years have laid the foundations and estab. lished the essential facts which form the basis of all development work.

Since the jubilee meeting just referred to, the Council of the Institution of Electrical Engineers has decided to change the name of the Section from "Wireless" to "Radio", and to extend its scope to cover the field generally known nowadays as "electronics". In this way the Institution has shown itself fully alive to the progress of the art and science of radio technique, and to the necessity of keeping this Section virile and up-to-date, and capable of representing the best interests of those engaged in the radio profession.

The chairman of this Radio Section for the current year is Mr. H. L. Kirke, head of the Research Department of the B.B.C. ; and on October 11 he delivered his inaugural address to the Section, the members of which now number about two thousand. In the first portion of his address, Mr. Kirke referred to the fact that it has been felt for some time that there ought to be closer co-operation with the Institute of Radio Engineers of America. War conditions made a definite move rather difficult, and it was clear that the matter needed oral discussion. An opportunity for this occurred early this year, when both Mr. Kirke and Dr. Smith-Rose, a past chairman of the Radio Section, were in the United States; they were invited, together with Mr. F. S. Barton, also a member of the Section and recently a vice-president of the American body, to attend a meeting of the Board of Directors of the Institute of Radio Engineers in New York. At this meeting a number of proposals were discussed and very well received; and in order to put these into effect, a special Liaison Committee has been formed in Great Britain to work with a similar committee in the United States. Thus a close link has been forged between the Radio Section of the Institution of Electrical Engineers in Great Britain and the Institute of Radio Engineers in the United States ; and it is hoped that, as a result, there will be a freer interchange between the two bodies of papers, discussions and other matters of mutual interest.

In the second part of his address, Mr. Kirke dealt with the subject of impedance measurement at radio frequencies. There has been considerable development in this field over the past decade. Mr. Kirke described, with the aid of diagrams and photographs and an exhibition of the apparatus, five types of radio-frequency bridge which have been developed and used during the past ten years: reference was also made to the associated apparatus and to a low- 
frequency capacitance bridge which was the forerunner of some of the radio-frequency equipment. Those interested in this type of apparatus technique will look forward to the publication of the address in the Proceedings of the Radio Section of the Institution.

\section{GEOLOGICAL SERVICE OF THE U.S.S.R.}

$\mathrm{T}$ $\mathrm{HE}$ Soviet Geological Service is working hard on problems connected with the defence of the country, the development of industry and the rehabilitation of the national economy of the liberated regions.

I. I. Malyshev, the chairman of the Geology Committee of the Council of People's Commissars, states that this year Soviet geologists are concentrating on a search for new mineral deposits. The Committee has already sent out more than six hundred parties of geologists and experts for field work.

Newer methods of work have been adopted, among which is the use of geophysical instruments which reveal the magnetic, gravitational, seismic and other features of rocks. The employment of these methods in past years has led to a number of discoveries being made. For example, an aeromagnetic survey of Western Siberia led to the discovery of new iron ore deposits.

This year's prospecting is mainly to find new deposits of molybdenum, tungsten, tin, mercury, mica, etc. Great importance is placed on these surveys as increased quantities of raw materials are needed for the iron and steel mills now being built in Siberia, Kazakhstan and other parts of the country.

It is hoped soon to complete the work on composite hydrogeological maps of the industrially and economically important regions of the U.S.S.R. These maps will show sub-soil waters, their quality, the conditions under which they are found, and the possibility of their being used for industry, transport, agriculture, and the water supply of inhabited centres. This information is valuable in planning the economic development of the districts concerned. In compiling these maps, data obtained by specially organized hydrogeological expeditions were added to the mass of available geological material. An example of the importance of the work done in the realm of hydrogeology is the discovery last year of deposits of fresh, sub-soil water at an accessible depth in the seemingly waterless Kara Kum desert.

All work and expeditions of this nature are under the direction of the All-Union Research Institute for Hydrogeology and Engineering Geology. The AllUnion Commission on Mineral Deposits will this year confirm the estimate of coal supplies available to all enterprises in the coal-mining industry; and the same will be done for the oil industry.

The scope of the State Geological Survey has been increased by almost 50 per cent this year. The Survey will give a complete picture of the geological structure of the U.S.S.R. and provide the foundation for all future prospecting and survey work. Aerial photographs are extensively used for this work.

Another important institution is the All-Union Geological Records which collects material on all the geological work done on Soviet territory. This year it is compiling a sort of encyclopædia of all known mineral deposits of the U.S.S.R. which will run into about 16,000 printed pages.

Soviet geologists are also busy at the front. Special detachments of geologists are working on all sectors of the front providing geological data for the advancing Red Army.

They supply the staff with necessary information when the Red Army has to force water-courses, pointing out places through which tanks can pass, help in organizing the army's water supply, search for building materials for dug-outs, roads and bridges, and give advice regarding camouflage. This work is frequently carried out under enemy fire. The selfless work of many geologists at the front has been marked by the award of Government decorations.

\section{ECONOMY IN THE USE OF DRUGS}

7 HE first edition of the Medical Research Council's War Memorandum No. 3, entitled "Economy in the Use of Drugs in War-time", was issued in March 1941. It represented the views of the Council's Therapeutic Requirements Committee and a first Supplement to it was issued in November 1941. A second revised edition is now issued (H.M. Stationery Office, 1944. 3d.). It includes an appendix on economy in the use of bactericides and disinfectants, large quantities of which are, the appendix says, used in hospitals and private practice under conditions in which they are not likely to be effective. Sterilization by heat is always preferable to the use of disinfectants and should be used if possible. Mercurial disinfectants have to be imported, and mercury is required for munitions, so that the indigenous coal-tar disinfectants should be used as much as possible. The same Council's War Memorandum No. 6 on "Prevention of 'Hospital Infection' of Wounds" contains recommendations for the use of disinfectants of the phenolic type.

An appendix to the first edition of the Memorandum described the production of drugs in the British Empire, but "the activities arising in this connection" have since been assumed by the Vegetable Drugs Committee set up by the Minister of Health. This Committee now works within the organization of the Ministry of Supply. Responsibility for the provision of drugs and therapeutic substances is now vested in the Ministry of Supply, which acts in consultation with the Ministry of Health, and both Ministries are represented on the Therapeutic Requirements Com. mittee. Difficulties in obtaining supplies of important drugs should be referred to the Directorate of Medical Supplies, Ministry of Supply, Portland House, Tothill Street, London, S.W.1.

This second edition of the Memorandum revises and extends the lists given in the first edition. It adds many new items and incorporates the first Supplement. Further, the method of classifying the substances listed has been changed. In the first edition Class $A$ brought together drugs which were regarded as essential and those which were readily available without indicating which of these reasons determined the inclusion of particular drugs in this Class. At the time of publication it was undesirable to publish this information. It has, however, become increasingly difficult to keep separate the ideas that a drug may be on one hand readily available and on the other essential. Too rigid a classification may defeat its own object unless there is a rigid scheme of rationing, 